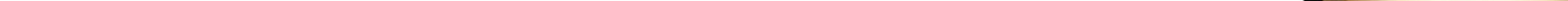




\section{Review of Postcolonial Theory and Avatar}

Postcolonial theory is dead and in need of reinvention, according to Gautam Basu Thakur in his incisive book Postcolonial Theory and Avatar. Identifying today's globalization as an ideological continuation of the West's colonial dominance during the past two centuries, the author argues that current postcolonial theory is unable to offer a critique of this "new avatar of European imperialism" (p. 6). Unlike during colonial times when the colonizers legitimized their oppression of the natives by representing them as savage and inferior subjects, today the cultures of the West's Other are not merely tolerated but rather celebrated as constituents of cultural diversity. Through this politically correct gesture of celebrating the Other, the West self-complacently defines itself as the promulgator of multiculturalism, thereby justifying its global capitalist hegemony. In order to respond critically to this twenty-first century situation, the author proposes that the focus of postcolonial criticism should go beyond representation of the native Other to encompass the West's formation of its own subjectivity. Basu Thakur's characterization of colonialism as essentially pertaining to Europe or the West, terms which he uses interchangeably throughout the book, may understate historical and ongoing examples of non-European colonialism (Japan's internal colonialism in Okinawa comes to this reviewer's mind). Nonetheless, his updating of postcolonial theory enables an acute critique of global capitalism, as he demonstrates through his analysis of James Cameron's 2009 sci-fi blockbuster, Avatar.

In the first half of his book, Basu Thakur overviews some of the criticism toward postcolonial theory as currently institutionalized in academia and then revisits the theories of Frantz Fanon and the "Holy Trinity" (p. 33) of Said, Bhabha, and Spivak. Although the works of some of those theorists are notorious for being densely theoretical, Basu Thakur suggests that the 
fundamental problem of current postcolonial theory is the result not of overtheorizing but of the lack of theoretical rigor. Having lost relevance to the actual economic and political struggle, postcolonial criticism has degenerated into tireless scrutiny of representations of the Other and clings to a simplistic plea for giving a voice to the oppressed. As Basu Thakur correctly points out, such a voice is sanctioned only within the boundaries set by the West and is fiercely suppressed as soon as the Other steps out of that tolerated zone as, for example, in the form of an armed revolt. In this sense, the lack of theoretical introspection in postcolonial theory has led to complicity with Western hegemony.

Basu Thakur's criticism is most iconoclastic when directed toward the academic discipline of film studies and its responses to Third Cinema. Complaining about insufficient attention being given to the West's construction of its own identity, he specifically accuses Paul Willemen of equating Third Cinema with national cinema and of being interested only in Third World films' articulation of the historical specificities of decolonized nations. In a tone echoing the Jameson/Ahmad debate on national allegory nearly three decades ago, Basu Thakur writes, "Willemen only appears to speak for the Third World's rights. His actual intention is to rephrase intellectually the narrative of the West as the only universal versus the East as particularly marked" (p. 74). I do not intend to defend Willemen against this charge here, yet the book's discussion reminds me of Professor Willemen's undergraduate course on British cinema, which I took as an exchange student at the University of Ulster in 2007. I remember the essay questions he gave instructed us to discuss canonical British films, such as Powell and Pressburger collaborations and Hammer horrors, in "a Third Cinemaly way." Contrary to Basu Thakur's claim, Willemen had been urging us to use the concept of Third Cinema as a methodological framework to critique from postcolonial perspectives the universality of "the narrative of the West" (in this case by tracing the

CINEJ Cinema Journal:Review of Postcolonial Theory and Avatar Volume 5.2(2016) | ISSN 2158-8724 (online) ｜ DOI 10.5195/cinej.2016.153 | http://cinej.pitt.edu 
legacy of British imperialism in the films). Willemen's revised approach to Third Cinema would certainly have materialized, had he lived long enough.

For Basu Thakur, Avatar "revises the image of the West from a racist, imperialist, political bully to that of a multicultural, tolerant, racially and ecologically sensitive subject" (p. 87). By way of contrast with the clearly demonized US military corporatism, the film's protagonist Sully is constructed as a liberal-minded white subject. Even though Sully in fact usurps the native culture of the $\mathrm{Na}$ 'vi by transforming into a $\mathrm{Na}$ 'vi himself and taking the role of their tribal leader, the film justifies his dominance over the native Other as it portrays the $\mathrm{Na}$ 'vi as helpless and incapable of politically organized resistance without the white hero's leadership. Using the Freudian concept of fetishism, Basu Thakur characterizes the viewers as fingertip activists who "advocate their cause on Facebook and donate to charities for quick resolution of their travails" (p. 146), and indicts them for their complicity in the film's construction of a rosy image of the new Western identity. The film enables such an audience to "fulfill their moral obligation of protesting against US imperialism without having to assume the radical extent of rallying furiously against the corporate-state nexus or supporting the indigene engaged in armed revolution" (p. 146). Although Basu Thakur's psychoanalytically informed speculations about the film's audience are supported only by sketchy reception research and thus risk reducing the global audience to a homogenous entity, they seem to explain aptly the film's worldwide success.

What makes this book particularly compelling is the author's strong voice. Basu Thakur dismantles and revamps postcolonial scholarship with firm conviction, and his film analysis is driven by a desire to uncover what he sees as the truth behind Avatar's beguiling surface. Accordingly, his discussion of the film is peppered with such words as "hidden/hide/conceal" (pp. 90, 104, 145), "façade" (p. 96), "lurks behind" (p. 110), "truth" (pp. 
99, 109), and "really/real" (p. 104). These expressions seem to indicate an essentialist assumption that there exists a unique, invariable truth that can be discerned and revealed through analysisan assumption of which postcolonial theory has always been cautious. I would have hoped to see more rigorous self-reflection in the author's discussions.

\section{Reviewer Contact Details}

Name: Kosuke Fujiki

Title: $\mathrm{PhD}$ candidate

Affiliation: King's College London

Address: 447 Norfolk Building, Strand Campus, London, WC2R 2LS, United Kingdom

Email: kosuke.fujiki@kcl.ac.uk 